o. SL-82-2

op. 3

\title{
DURABILITY OF POST-TENSIONED CONCRETE BEAMS EXPOSED TO SEVERE NATURAL WEATHERING
}

by

Edward F. O'Neil

Structures Laboratory

U. S. Army Engineer Waterways Experiment Station

P. O. Box 631, Vicksburg, Miss. 39180

April 1982

Final Report

Approved For Public Release; Distribution Unlimited

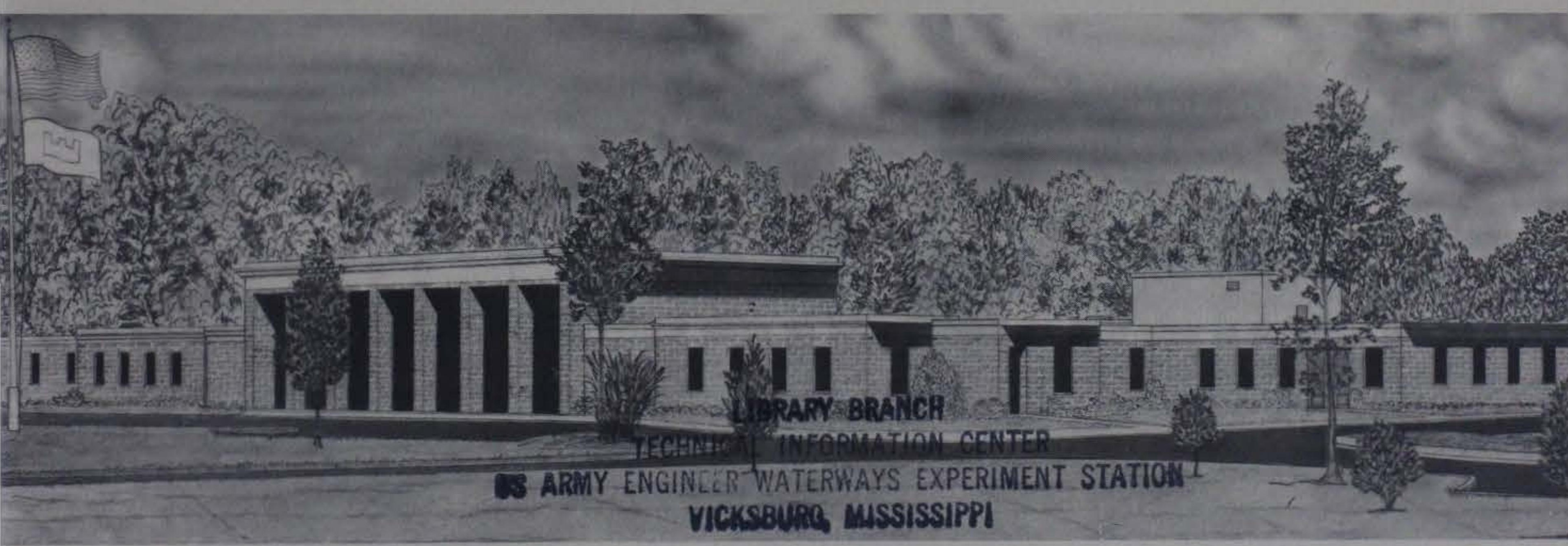

Prepared for Office, Chief of Engineers, U. S. Army

Washington, D. C. 20314 


\begin{tabular}{|c|c|}
\hline REPORT DOCUMENTATION PAGE & $\begin{array}{l}\text { READ INSTRUCTIONS } \\
\text { BEFORE COMPLETING FORM }\end{array}$ \\
\hline $\begin{array}{l}\begin{array}{l}\text { 1. REPORT NUMBER } \\
\text { Miscellaneous Paper SL-82-2 }\end{array} \\
\text { 2. GOVT ACCESSION NO. }\end{array}$ & 3. RECIPIENT'S CATALOG NUMBER \\
\hline \multirow{2}{*}{$\begin{array}{l}\text { 4. TITLE (and Subtitle) } \\
\text { DURABILITY OF POST-TENSIONED CONCRETE BEAMS } \\
\text { EXPOSED TO SEVERE NATURAL WEATHERING }\end{array}$} & $\begin{array}{l}\text { 5. TYPE OF REPORT \& PERIOD COVERED } \\
\text { Final report }\end{array}$ \\
\hline & 6. PERFORMING ORG. REPORT NUMBER \\
\hline $\begin{array}{l}\text { 7. AUTHOR(0) } \\
\text { Edward F. O'Neil }\end{array}$ & 8. CONTRACT OR GRANT NUMBER(*) \\
\hline $\begin{array}{l}\text { 9. PERFORMING ORGANIZATION NAME AND ADDRESS } \\
\text { U. S. Army Engineer Waterways Experiment Station } \\
\text { Structures Laboratory } \\
\text { P. O. Box } 631 \text {, Vicksburg, Miss. } 39180\end{array}$ & $\begin{array}{l}\text { 10. PRCGRAM ELEMENT, PROJECT, TASK } \\
\text { AREA \& WORK UNIT NUMBERS }\end{array}$ \\
\hline \multirow{2}{*}{$\begin{array}{l}\text { 11. CONTROLLING OFFICE NAME AND ADDRESS } \\
\text { Office, Chief of Engineers, U. S. Army } \\
\text { Washington, D. C. } 20314\end{array}$} & $\begin{array}{l}\text { 12. REPORT DATE } \\
\text { April } 1982\end{array}$ \\
\hline & $\begin{array}{l}\text { 13. NUMBER OF PAGES } \\
15\end{array}$ \\
\hline \multirow[t]{2}{*}{ 14. MONITORING AGENCY NAME \& ADDRESS(If different from Controlling Offico) } & $\begin{array}{l}\text { 15. SECURITY CLASS. (of thlo roport) } \\
\text { Unclassified }\end{array}$ \\
\hline & $\begin{array}{l}\text { 15a. DECLASSIFICATION/DOWNGRADING } \\
\text { SCHEDULE }\end{array}$ \\
\hline
\end{tabular}

Approved for public release; distribution unlimited.

17. DISTRIBUTION STATEMENT (of the abstract ontered in Block 20, if difforent from Roport)

18. SUPPLEMENTARY NOTES

Available from National Technical Information Service, 5285 Port Royal Road, Springfield, Va. 22151.

This is CTIAC Report No. 50.

19. KEY WORDS (Continue on reverse side if necessery and identify by block number)

Concrete--Deterioration

Concrete--Testing

Concrete beams

Weathering

20. ABSTRACT (Continus an moverse atid it mecoeseary and tdentily by block number)

A study of the durability of post-tensioned concrete beams and of the types of end caps used to protect the anchorage systems from deterioration when subjected to severe environmental conditions was conducted. Twenty posttensioned concrete beams 254 by $406 \mathrm{~mm}$ ( 10 by 16 in.) in cross section and $2.44 \mathrm{~m}(8 \mathrm{ft})$ in length were cast, post-tensioned, and placed at the mean tide elevation on the beach at Treat Island off the coast of Eastport, Maine. The beams were subjected to twice daily wetting and drying cycles plus an average (Continued) 


\section{ABSTRACT (Continued)}

of 130 freezing and thawing cycles per winter for a period of 12 to 13 years.

During this exposure period, the beams were inspected annually to determine the condition of each end cap or plug, the joint between beam and cap or plug, and the beams themselves.

At the end of the exposure period, eight representative beams were returned to the laboratory for autopsy and analysis of the protective caps, the method of joint preparation, and the post-tensioning steel being protected.

The results of the durability investigation indicated, among other findings, that the end protective caps attached to the beams by reinforcing bars across the cap/beam joint experienced no cap failures; the epoxy concrete end caps provided the best protection to the end anchorages of all methods tested; and the post-tensioning wires in the beams experienced no structural damage over the exposure period provided they were encased in a flexible metal conduit and protected with portland cement grout. 


\section{$\underline{\text { Preface }}$}

This report is essentially a paper prepared for presentation at the First International Conference on Durability of Building Materials and Components. This conference, sponsored by the National Research Council of Canada, was held 21-23 August 1978 in Ottawa.

The research that produced the results given in this paper was conducted as part of Engineering Study 031 (formerly Civil Works Investigation Item CW031) for the Office, Chief of Engineers, U. S. Army (OCE), with recommendations from the Reinforced Concrete Research Council. The research was done in the Concrete Technology Division (CTD) of the Structures Laboratory (SL), U. S. Army Engineer Waterways Experiment Station (WES). Original approval for the investigation was given by multiple letter, dated 11 December 1956, from OCE.

Funds for publication of the report were provided from those made available for operation of the Concrete Technology Information Analysis Center (CTIAC). This is CTIAC Report No. 50. The paper was prepared by Mr. Edward F. O'Neil under the general supervision of Messrs. Bryant Mather, Chief, SL; John M. Scanlon, Chief, CTD; and James E. McDonald, Chief, Evaluation and Monitoring Group.

Commander and Director of WES during preparation of this report was COL T. C. Creel, CE. Technical Director was Mr. F. R. Brown. 


\section{Contents}

$\underline{\text { Page }}$

Preface . . . . . . . . . . . . . . . . . . 1

Exposure Study . . . . . . . . . . . . . . . . . . 3

Description of the Beams ............... 3

Additional Reinforcement ............. . 4

Exposure Conditions ................ . . 4

Inspection Schedules ............... 6

Laboratory Testing . . . . . . . . . . . . . . 6

Results and Discussion ................ 7

Condition of the Beams and and Conventional Reinforcement . . . . . . . . . 7

Condition of the Concrete End Anchorage Protection . . . . . . . . . . . . . . . 8

Condition of the Beam End Preparation . . . . . . . . . . . 9

Condition of the PT Wires . . . . . . . . . . . . 10

Structural Tests ................. . 14

Conclusions . . . . . . . . . . . . . . . . . 15 


\section{Durability of Post-Tensioned Concrete Beams Exposed to Severe Natural Weathering}

The durability of post-tensioned concrete depends largely upon the properties of the concrete and the means taken to protect the post-tensioning (PT) steel from corrosion. The protection of the PT steel and the anchorage systems was the subject of a study conducted at the U.S. Army Engineer Waterways Experiment Station (WES), to evaluate different types of protective concrete and methods of attaching them to post-tensioned beams to provide the best corrosion protection to the steel.

\section{Exposure Study}

Description of the Beams - Twenty post-tensioned concrete beams 254 by $406 \mathrm{~mm}$ in cross section and $2.44 \mathrm{~m}$ in length were fabricated and tensioned at the WES and sent to a severe weathering station at Treat Island, Me., 
to be subjected to daily cycles of wetting and drying and cycles of freezing and thawing during the winter. The makeup of the 20 beams consisted of four types of PT systems and twelve types of end anchorage protection. These conditions are shown in Table 1. Nineteen of the beams contained PT systems surrounded by a flexible metal conduit and were filled with grout after being post-tensioned. The other beam contained unbonded, post-tensioned wires that were spiral wrapped with paper and the paper conduit filled with a mineral grease after the wires were post-tensioned. There were two kinds of concrete protections: caps and plugs. The caps were formed to fit over an end anchorage that was extending from the end of the beam. Each cap had cross-sectional dimensions that were the same as those of the beam and was $152.5 \mathrm{~mm}$ deep. The plugs covered end anchorages that were recessed into the end of the beam, and they had dimensions smaller than the end of the beam such that the beam itself acted as formwork when placing the end plugs. The end anchorage caps or plugs were attached to the ends of the beams with four different types of beam preparation to determine if preparation of the surface of the beam would aid in the protection of the steel and end anchorages. Ten of the ends of the beams received either caps or plugs on concrete that had no preparation. Eight of the ends of the beams were bush hammered to roughen the surface before the cap or plug was placed. Four of the beams had one end treated with a retarding agent, and six ends of the beams received epoxy coatings over the end of the beam before the cap or plug was cast. Ten of the caps or plugs were made of epoxy concrete and two of the plugs were only sand-cement mortar. In the 40 ends of the 20 beams twelve ends had reinforcement protruding from the end of the beam into the end cap to aid in holding the cap to the beam.

Additional Reinforcement-In addition to the PT steel, the beams contained conventional reinforcement consisting of longitudinal bars at the four corners of the beam and shear stirrups spaced equally along the length of the beam. The conventional reinforcement was given $19 \mathrm{~mm}$ of cover to determine whether that amount of cover would provide protection.

Exposure conditions - The 20 beams were exposed at the Treat Island, Me., exposure station. Treat Island is located in Cobscook Bay, east of Eastport, Me. The beams were placed on the beach at the mean tide elevation with one end of the beams facing seaward and the other landward. There they were subjected to tidal inundations and drying periods twice daily for 12 to 13 years plus freezing in air and thawing in seawater during 


\begin{tabular}{|c|c|c|c|c|c|}
\hline \multirow[b]{2}{*}{ Beam No. } & \multirow[b]{2}{*}{$\begin{array}{c}\text { PT } \\
\text { System }\end{array}$} & \multirow{2}{*}{$\begin{array}{c}\text { Eccentricity } \\
\text { of Tendon. } \\
\mathrm{mm} \text { (in.) }\end{array}$} & \multirow{2}{*}{$\begin{array}{l}\text { Estimated } \\
\text { Final PT } \\
\text { Force, } \\
\text { kN (tons) }\end{array}$} & \multicolumn{2}{|c|}{$\begin{array}{c}\text { Type of End Protection }{ }^{b} \\
\text { (See Note) }\end{array}$} \\
\hline & & & & $\begin{array}{l}\text { Landward } \\
\text { End }\end{array}$ & $\begin{array}{l}\text { Seaward } \\
\text { End }\end{array}$ \\
\hline $1^{c}$ & A & $0(0)$ & $204.6(23)$ & Plug (1) & Cap (5) \\
\hline 2 & A & $0(0)$ & $204.6(23)$ & Cap (4) & Cap (2) \\
\hline $3^{c}$ & A & $76(3)$ & $204.6(23)$ & Cap (3) & Cap (1) \\
\hline 4 & A & $51(2)$ & $204.6(23)$ & Cap (7) & Plug (7) \\
\hline 5 & A & $51(2)$ & $204.6(23)$ & Cap (6) & Plug (6) \\
\hline $6^{c}$ & A & $25(1)$ & $204.6(23)$ & Plug (9) & Cap (8) \\
\hline 7 & B & $0(0)$ & $231.3(26)$ & Cap (1) & Plug (1) \\
\hline 8 & B & $51(2)$ & $231.3(26)$ & Cap (2) & Cap (4) \\
\hline $9^{c}$ & B & $76(3)$ & $231.3(26)$ & Cap (3) & Cap (5) \\
\hline 10 & B & $76(3)$ & $231.3(26)$ & Plug (6) & Cap (6) \\
\hline $11^{c}$ & B & $25(1)$ & $231.3(26)$ & Plug (7) & Cap (7) \\
\hline 12 & B & $25(1)$ & $231.3(26)$ & Cap (8) & Plug (9) \\
\hline $13^{c}$ & $\mathrm{C}$ & $0(0)$ & $266.9(30)$ & Cap (1) & Cap (3) \\
\hline 14 & C & $25(1)$ & $266.9(30)$ & Cap (2) & Cap (4) \\
\hline $15^{c}$ & $\mathrm{C}$ & $76(3)$ & $266.9(30)$ & Cap (5) & Cap (6) \\
\hline 16 & C & $51(2)$ & $266.9(30)$ & Cap (7) & Cap (8) \\
\hline 17 & D & $76(3)$ & $373.6(42)$ & Cap (1) & Cap (3) \\
\hline 18 & D & $0(0)$ & $373.6(42)$ & Cap (4) & Cap (2) \\
\hline $19^{c}$ & D & $51(2)$ & $373.6(42)$ & Cap (5) & Cap (6) \\
\hline 20 & $\mathrm{D}$ & $25(1)$ & $373.6(42)$ & Cap (8) & Cap (7) \\
\hline
\end{tabular}

"A through D represent four different commercial post-tensioning systems used.

${ }^{b}$ Concrete placed against a cold joint with no surface treatment and no reinforcement Cap (1) and Plug (1)).

Concrete placed against a cold joint with no surface treatment but with reinforcement (Cap (2)).

Concrete placed against a hush-hammered surface and with no reinforcement (Cap (3)). Concrete placed against a bush-hammered surface but with reinforcement (Cap (4)). Concrete placed against a surface that had been treated with a retarding agent and no reinforcement (Cap (5)).

Concrete bonded to the ends of the beam with an epoxy adhesive and no reinforcement (Cap (6) and Plug (6)).

Epoxy concrete without reinforcement (Ext (7) and Plug (7)).

Epoxy concrete with reinforcement (Cap (8)).

Sand-cement mortar with alumimum powder additive, comparatively dry and well tamped (Plug (9)).

'Beams that were examined in the laboratory. 
the winter months. The beams were considered to have undergone one cycle of freezing and thawing when the temperature had passed below $-2^{\circ} \mathrm{C}$ and then passed above this temperature. During the exposure period the average number of cycles of freezing and thawing was 130 per winter.

Inspection Schedules-The beams were monitored weekly by a caretaker from Eastport and rated yearly by a team of inspectors composed of government and industry personnel. During the yearly inspection tours the team compiled ratings on observations of the end anchorage protection, the joints between the end anchorage protection and the beam, and the beam itself. They rated these variables from a perfect rating of zero to a totally failed rating of 28 . Their ratings were based on the amount of rust showing on the concrete, the degree of spalling to the beam, the joint, and the cap, and the condition of the steel that had been exposed by spalling.

Laboratory Testing-After 12 years of exposure, five beams were returned to the laboratory for autopsy and testing to determine the amount of deterioration to the concrete and the PT systems. Three additional beams were returned after 13 years. In the laboratory the beams were failed structurally, and the concrete removed from around the conventional reinforcing and the PT conduits by means of an air hammer. The conventional reinforcement was catalogued to record the amounts and description of rust on the surface, and the condition of the exterior of the PT conduit and end anchorage was observed. Subsequent to this the conduits were opened and the rust on the PT wires was catalogued. In order to analyze the rust it was scraped from the wires and subjected to $\mathrm{X}$-ray diffraction analysis. The wires were then measured at $51-\mathrm{mm}$ intervals àlong their length and a section of the least diameter from each end and the middle of each wire was structurally tested according to ASTM Standard Methods and Definitions for Mechanical Testing of Steel Products (A 37068).

The chloride content of both the concrete and the grout that filled the PT conduits was determined by a silver nitrate titration test described by Berman. ${ }^{2}$ In addition to these tests, grout density and $\mathrm{pH}$ were recorded to determine if the grout had been of inferior quality or invaded by chlorides. ${ }^{2}$ Berman, H. A., Journal of Materials, American Society for Testing and Materials, Vol. 7.
No. 3, Sept. 1972, pp. 330-335. 


\section{Results and Discussion}

Condition of the Beams and Conventional Reinforcement-From the results of the annual visual inspection of the beams it was found that spalling and corrosion to the conventional reinforcement had begun after only 2 years. Observation of the beams when returned to the laboratory showed large areas of concrete spalled from the longitudinal reinforcement and the reinforcement that was exposed had corroded heavily. Figure 1 shows a typical beam with the heavy spalling adjacent to the longitudinal reinforcement. This photograph also shows the beam relatively unspalled in the area where the stirrups are located. When the beams were broken open and the reinforcement cage removed it was found that the stirrups were relatively uncorroded.

The heavy spalling to the concrete surrounding the conventional, longitudinal reinforcement was caused by penetration of oxygen and salt water to the level of the steel and a chloride concentration at that level sufficient to destroy the passivating oxide coating on the steel. This condition caused rusting of the steel and tensile stresses in the concrete from the buildup of rust products sufficient to spall the concrete from the beam. This condition confirms the fact that a $19-\mathrm{mm}$ cover of concrete over conventional reinforcement is insufficient to protect the steel in a severe weathering

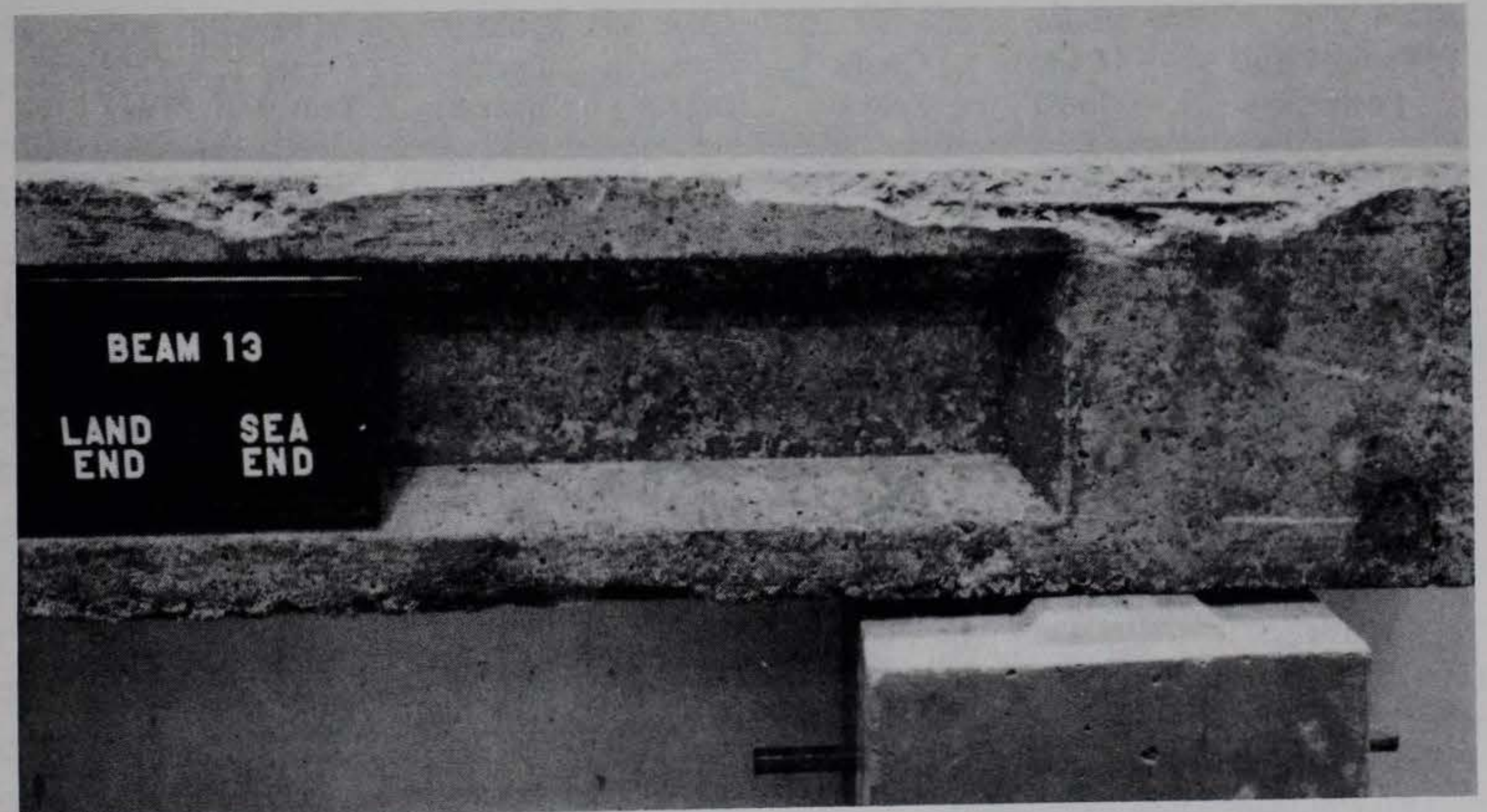

FIG. 1-Condition of spalling and corrosion to the reinforcement of Beam 13. 
atmosphere. It is believed that the stirrups remained relatively free from corrosion due to their becoming cathodic in relation to the corroding longitudinal steel. This, coupled with the fact that the longitudinal steel was located in the corners of the beam and susceptible to penetration of oxygen and moisture from two surfaces rather than just one in the case of the stirrups, caused the stirrups to receive smaller amounts of corrosion.

Condition of the Concrete End Anchorage Protection-The results of the annual inspections of the concrete end anchorage protections are given in Table 2 for the years $0,3,6,9$, and 12 . Based on the visual inspections, after 12 years of exposure, all the flush anchorage plugs had numerical ratings of 4 or less, while only two of the types of external anchorage caps had ratings as low as 4 , with the rest rated 10 to 16 . It should be noted that the averages that decreased between years nine and twelve did not indicate that the caps' condition improved, but that the average was taken on ends of the beams that still remained at the island.

TABLE 2-Tabulation of the visual evaluation of the types of end protection for years $0.3,6,9$, and 12 .

\begin{tabular}{|c|c|c|c|c|c|c|}
\hline \multirow[b]{2}{*}{$\begin{array}{l}\text { Type of End } \\
\text { Protection }\end{array}$} & \multirow{2}{*}{$\begin{array}{l}\text { No. of } \\
\text { Beam } \\
\text { Ends } \\
\text { Used }\end{array}$} & \multicolumn{5}{|c|}{$\begin{array}{c}\text { Average Condition at Indicated Time and } \\
\text { After Indicated No. of Cycles }\end{array}$} \\
\hline & & $\begin{array}{c}0 \\
\text { Cycles } \\
\text { Year } 0\end{array}$ & $\begin{array}{c}330 \\
\text { Cycles } \\
\text { Year } 3\end{array}$ & $\begin{array}{c}623 \\
\text { Cycles } \\
\text { Year } 6\end{array}$ & $\begin{array}{c}1118 \\
\text { Cycles } \\
\text { Year } 9\end{array}$ & $\begin{array}{c}1597 \\
\text { Cycles } \\
\text { Year } 12\end{array}$ \\
\hline Plug (1) & 2 & 0 & 1 & 2 & 0 & 2 \\
\hline Plug (6) & 2 & 0 & 0 & 0 & 0 & 0 \\
\hline Plug (7) & 2 & 0 & 2 & 2 & 4 & 4 \\
\hline Plug (9) & 2 & 0 & 0 & 2 & 0 & 0 \\
\hline Cap (1) & 4 & 0 & 7 & $11^{a}$ & $13^{a}$ & $16^{b}$ \\
\hline Cap (2) & 4 & 0 & 10 & 11 & 14 & 10 \\
\hline Cap (3) & 4 & 0 & 10 & $10^{a}$ & $14^{a}$ & $16^{b}$ \\
\hline Cap (4) & 4 & 0 & 11 & 13 & 15 & 12 \\
\hline Cap (5) & 4 & 0 & 3 & 2 & $10^{a}$ & $10^{a}$ \\
\hline Cap (6) & 4 & 0 & 9 & $9^{a}$ & $12^{a}$ & $14^{a}$ \\
\hline Cap (7) & 4 & 0 & 1 & 1 & 4 & 4 \\
\hline Cap (8) & 4 & 0 & 1 & 4 & 4 & 4 \\
\hline Total & 40 & & & & & \\
\hline
\end{tabular}

\footnotetext{
${ }^{a}$ One end protection has failed.
}

${ }^{b}$ Two end protections have failed. 
The concrete plugs weathered better than the end caps due to their orientation in the end of the beam. Actually the beams helped protect the plug. The flush plugs did not have any joints on horizontal surfaces (places where water could collect) and were not as exposed to the effects of freezing and thawing as were the end caps, which had joints on the top surface where moisture could collect and subsequently freeze. The freezing water expanded in the joint and this pressure in a confined space caused local failure of the concrete at the joint such that after thawing the space for water to collect was larger and more water could collect on the next cycle. In extreme cases this condition pried the cap completely away from the end anchorage.

The external end caps that did weather well were made of epoxy concrete. These caps were made by mixing sand and coarse aggregate with epoxy resin such that essentially all the cement content was replaced by epoxy, consequently there was no internal void system for water to penetrate and cause freezing and thawing deterioration. Also, since there was no water present the end anchorages protected by the epoxy caps showed less corrosion than anchorages protected by portland cement end caps.

Condition of the Beam End Preparation-The results of a visual analysis of the four types of end preparation used for the joints between the beams and the 13 external end caps are as follows: Three joints were prepared by bush hammering the surface of the joint at 32-33 days age to roughen the joint before placement of the end cap. Of these three joints, two were still intact at the end of the study period. One of these joints (at the seaward end of Beam 13) had a crack between the cap and the beam. The anchorages beneath these caps were corroded moderately to heavily, on the whole. Four of the joints were prepared by the use of a retarding agent. The inside surface of the form was coated with this retarder, and the concrete was placed against this surface. At 3 days age, the forms were stripped, and the retarded surface was scrubbed to remove the soft cement surface from the end of the beam, exposing some of the aggregate and producing a roughened surface. At the end of the study period, three of these joints were intact. The anchorages beneath these caps were corroded relatively heavily, with the heaviest corrosion on the landward end anchorage of Beam 19. Two of the joints were treated with an epoxy adhesive by coating the surface of the joint with the epoxy prior to casting the protective end cap over the joint, and of these two, one half of one remained intact. Both of these end anchorages were corroded heavily. Two of the joints 
received no preparatory treatment, and both of these were still intact, one of which (at the landward end of Beam 13) was cracked between the cap and the beam. The anchorages beneath these caps were corroded moderately (landward end of Beam 13) and free from corrosion (seaward end of Beam 3). The two epoxy concrete end protective caps were put onto a beam surface that was sandblasted and primed. Both of these were assigned a visual rating of 4 , and the inspection of the end anchorage revealed either no corrosion or very light to moderate corrosion.

There appears to be no strong correlation between method of preparation of the beam to receive end anchorage protection and the amount of corrosion to the anchorage beneath. The end caps that were pried away from their anchor obviously afforded the least protection to the anchorage, however, those types of preparation that did not result in failure of the end cap also showed moderate to heavy corrosion. With respect to tenacity of the concrete cap to the beam, the beams treated with the retarding agent performed the best, however, this did little for retarding the corrosion to the anchor. The anchorages beneath the epoxy concrete end caps were the least corroded, but this was not a method of preparation to the end of the beam to receive an end cap.

There did seem to be a correlation between the ability of an end cap to resist the forces of freezing and thawing and the sizes of the end anchor. Figure 2 shows the as-received condition of four of the end caps on Beams 15 and 19. The anchorages of Beam 19 were flat compared to those of Beam 15 and both the caps of Beam 19 were missing when returned to the laboratory. All the anchorages that had lost their end caps in this investigation were shallow in depth. In other words, the deeper an end anchorage is, the better its end cap will remain attached throughout any exposure period. This does not mean that the end anchorage will be well protected; however, if the end cap does pry loose, it has been determined that greater corrosion will occur on the steel. In this respect the depth of the end anchorages acted as reinforcement similar to the beams that had reinforcing bars running between the beam itself and the cap over the anchorage. Of the 40 joints on the 20 beams of the study, twelve had reinforcement between the beam and cap and none of these caps pried loose or cracked during the 12 to 13 years of exposure.

Condition of PT Wires-The steel within the PT conduits ranged from completely covered with rust to not rusted at all. The areas completely covered by rust were not confined to the ends of the wire and did not 
exhibit any trend associated with location in the conduit except for the wires of Beam 13 which had the conduit filled with grease. Although the majority of the wires were sometimes covered with rust, they were not corroded to any depth. The maximum loss in diameter of any wire, with the exception of the eight wires at the landward end of Beam 13 was $0.13 \mathrm{~mm}$.

Beam 13 had the worst corrosion at the ends. At the landward end of the wires on this beam, 87.5 percent of the wires were corroded heavily, and at the seaward end, 62.5 percent were corroded moderately. Just inside the landward end anchorage plate the diameters of the wires were all slightly smaller than the diameters of other parts of the wires, and the cross section of one wire was so reduced that it had broken $16 \mathrm{~mm}$ from the anchorage plate.

The PT wires showed much less corrosion than the end anchorages because of the grout protection that they received. The grout and the metal conduit used to encase the wires kept the seawater from penetrating to the surface of the wires. All the specimens of grout taken from the conduits gave $\mathrm{pH}$ readings between 12.13 and 12.90 , the lowest being from Beam 19 and the highest from Beam 3. These readings are all within the normal range for grout which is in the neighborhood of $12.50 .^{3}$ In contrast, the anchorages were only protected by the concrete cover which was vulnerable to saturation by seawater and chlorides. Analysis of the concrete and grout showed concentrations of chlorides as high as 0.36 percent in the concrete but less than 0.02 percent in the grout around the wires. Steel has a protective oxide coating on it in its natural condition that inhibits the action of corrosion. When encased in the highly alkaline environment of concrete or grout, this coating is protected; but high concentrations of chlorides reduce the alkalinity of the concrete and destroy the passivating film on the steel allowing water and oxygen to corrode the metal. This high chloride content was not present in the grout and consequently the steel did not corrode. Table 3 gives the properties of the grout and concrete used in this study.

The one set of wires that did corrode heavily was not protected by the grout or by a metal conduit. The paper conduit that encased the wires of

${ }^{3}$ Diamond, S., "Mechanics of Alkali-Silica Reaction and Expansion-A Review and Reassessment," unpublished. 

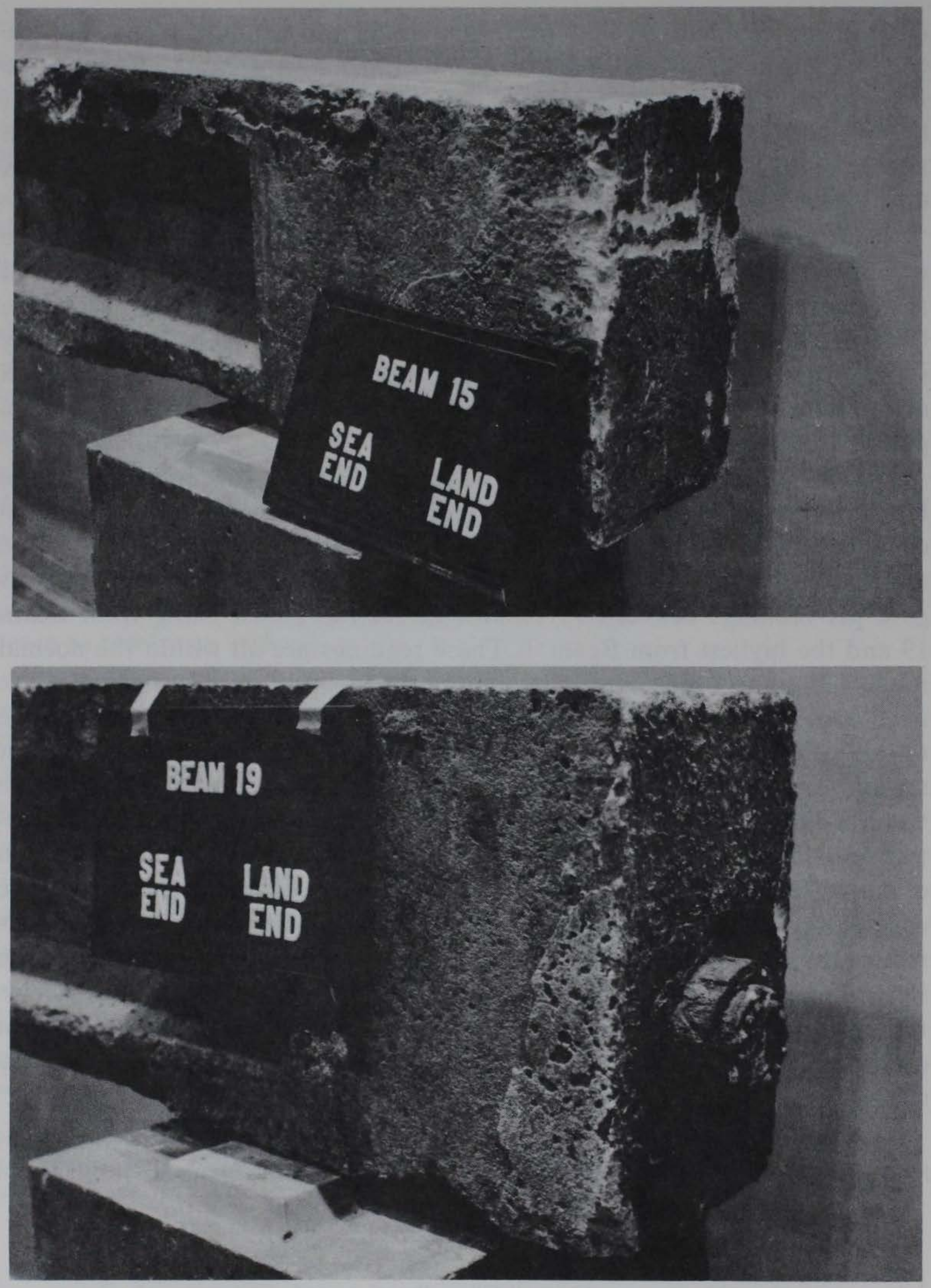

FIG. 2-Typical conditions of the end anchorage protection as returned from the exposure site. 

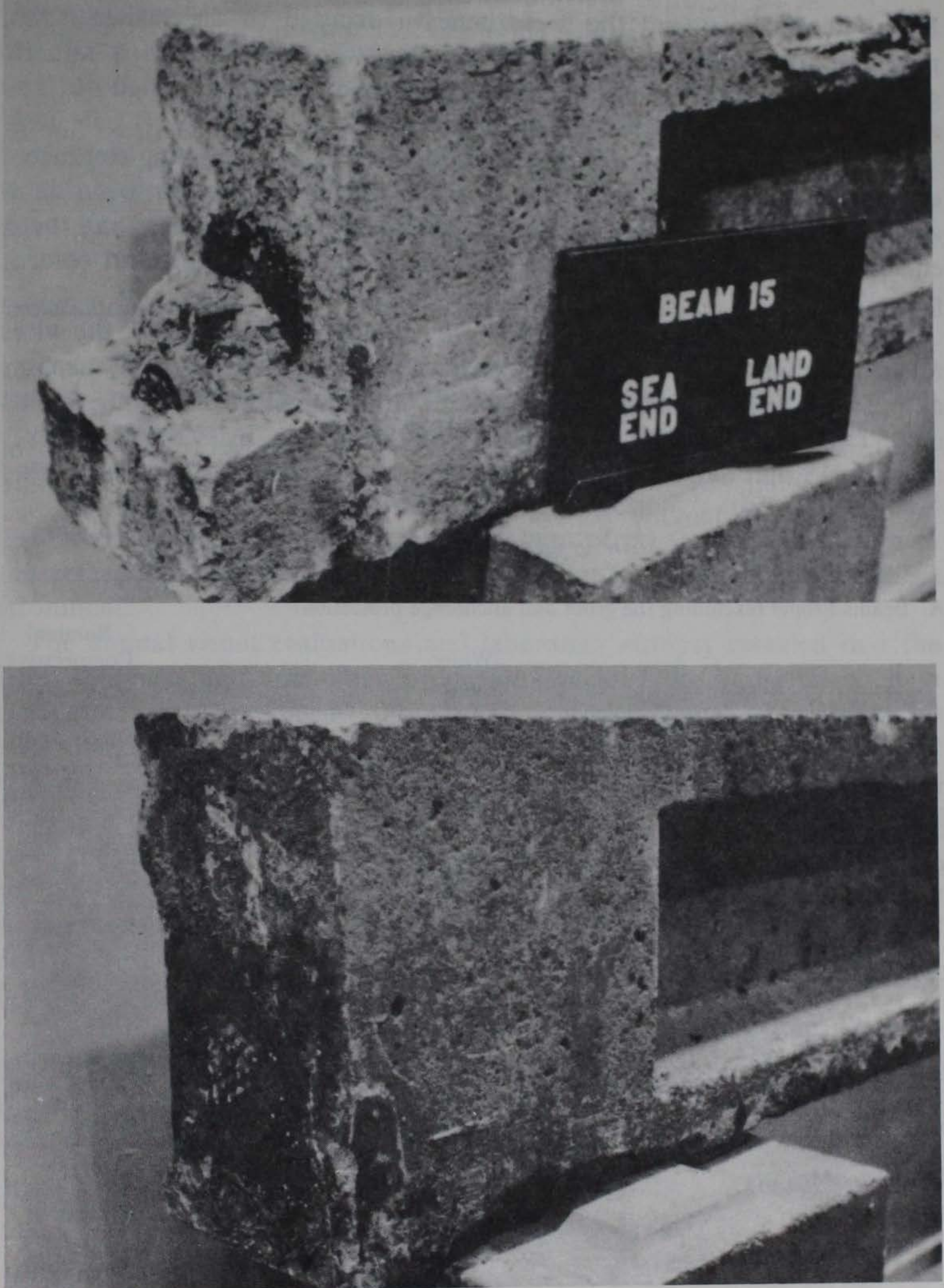

FIG. 2-Continued. 
Beam 13 was torn and the wires beneath exposed to the seawater that penetrated through the concrete. The wires were coated with a mineral grease, and over the 12-year period some of the grease had dried out and allowed air to get to the surface of the steel.

Structural Tests-The results of ASTM Method A 370 testing conducted on the sections of PT wires revealed that the PT wires had not been damaged structurally by the exposure conditions provided they had been enclosed in a metal conduit and the conduit filled with portland cement grout.

One hundred and fifty eight tests were conducted on sections of the wires taken from each end and the middle of each wire in the first five beams autopsied. Of these 158 tests only 22 tests did not pass all the requirements of ASTM Method A 370, and half of the 22 tests were from the eight wires of Beam 13 that had a paper conduit and was covered with mineral grease.

TABLE 3-Mixtures used to fabricate post-tensioned beams.

A. Beams Proper (excluding the grout and anchorage protection)

\begin{tabular}{|c|c|c|c|c|c|c|}
\hline Cement & $\begin{array}{c}\text { Max Size } \\
\text { Aggregate, } \\
\text { mm }\end{array}$ & $\begin{array}{c}\text { Air } \\
\text { Content, } \\
\%\end{array}$ & $\begin{array}{l}\text { Water- } \\
\text { Cement } \\
\text { Ratio } \\
\text { by wt. }\end{array}$ & $\begin{array}{l}\text { Slump, } \\
\text { mm }\end{array}$ & $\begin{array}{l}\text { Cement } \\
\text { Factor } \\
\mathrm{kg} / \mathrm{m}^{3}\end{array}$ & $\begin{array}{c}\text { Nominal } \\
\text { Compressive } \\
\text { Strength, } \\
\text { MPa ( } 28 \\
\text { Days Age) }\end{array}$ \\
\hline $\begin{array}{l}\text { Type III } \\
\text { (high-early- } \\
\text { strength) }\end{array}$ & 19 & $4.0-5.0$ & 0.52 & 38 to 51 & $\begin{array}{l}338.5 \\
337.4\end{array}$ & 41.37 \\
\hline \multicolumn{7}{|c|}{ B. Anchorage Protection (excluding epoxy mixture) } \\
\hline $\begin{array}{l}\text { Type III } \\
\text { (high-early- } \\
\text { strength) }\end{array}$ & 19 & $3.5-5.0$ & 0.80 & 32 to 51 & $\begin{array}{l}217.5 \\
220.8\end{array}$ & 20.68 \\
\hline
\end{tabular}

Max Size

Cement Aggregate, $\mathrm{mm}$

Mixture Proportions by wt.

Epoxy Binder: Sand: Compressive Strength, Coarse Aggregate $\quad \mathrm{MPa}$ (28 Days Age)

None

19

$2.83: 7.00: 10.00$

$64.26-78.05$

D. Mortar Mixtures

\begin{tabular}{ccccc} 
Cement & $\begin{array}{c}\text { Max Size } \\
\text { Aggregate }\end{array}$ & $\begin{array}{c}\text { Water-Cement } \\
\text { Ratio by wt. }\end{array}$ & $\begin{array}{c}\text { Cement Factor, } \\
\mathrm{kg} / \mathrm{m}^{3}\end{array}$ & $\begin{array}{c}\text { Compressive } \\
\text { Strength, MPa } \\
\text { (28 Days Age) }\end{array}$ \\
\hline $\begin{array}{c}\text { Type III } \\
\text { (high-early- } \\
\text { strength) }\end{array}$ & $\begin{array}{c}100 \% \text { passing } \\
\text { No. } 4 \text { sieve }\end{array}$ & 0.44 & 607.9 & $53.16-53.78$ \\
\hline
\end{tabular}


Of these eleven tests of Beam 13 PT wires all of the wires at the landward end failed to meet total elongation requirements and one also failed to meet ultimate strength requirements. It appears that the exposure that the wires at the landward end of Beam 13 received had caused some embrittlement since all the wires had low elongations. The remaining eleven tests that did not pass were distributed throughout the rest of the beams and were associated with low ultimate strengths and small elongations.

\section{Conclusions}

The results of 12 and 13 years of severe weathering exposure to the 20 beams described in this study yield the following conclusions about durability, method of protection to end anchorages, method of surface preparation, and type of PT system.

The heavy spalling to the concrete and corrosion to the conventional reinforcement confirms the fact that $19 \mathrm{~mm}$ of cover is not sufficient to protect steel reinforcement from corrosion in a severe weathering environment.

The annual visual evaluations and laboratory autopsy revealed that the epoxy concrete end anchorage protection provided the best protection to the end anchorages due to the exclusion of the elements necessary for corrosion.

There is no correlation between method of beam end preparation and condition of the anchorage of the beam, however, as concerns the use of end caps, end anchorages that had substantial depth acted as reinforcement to hold the end cap in place.

The use of a spirally wrapped paper conduit filled with mineral grease did not protect the PT wires from corrosion significant enough to cause failure of one of the wires under load.

The results of structural testing of the PT wires showed that 12 to 13 years of severe weathering exposure did not structurally damage the steel providing the wires were encased in a flexible metal conduit and grouted completely with portland cement grout after PT. 